\title{
Social Citizenship, Democratic Values and European Integration: A Rejoinder
}

\author{
Maurizio Ferrera
}

This Forum debate has gone way beyond my expectations and hopes. I thought that commentators would mainly address my proposals on enhancing rights and introducing duties. The conversation has instead extended to my diagnosis as well, to the rationale which lies at the basis of my prescriptive ideas. By focusing on starting points, the forum has thus brought into light different perspectives and styles of reasoning around citizenship and even broader political questions. With hindsight, I should have spelled out more carefully my basic assumptions. But there is time to remedy this now and not just for the sake of this particular discussion. I am in fact convinced that a closer and more systematic dialogue between empirical, normative, legal and social theorists would be a welcome and beneficial innovation, a way to contrast excessive disciplinary perspectivism and the related risks of analytical lock-ins.

I will begin this rejoinder by addressing the disagreement on starting points. I will then move to general issues of democracy, citizenship and social rights. Next, I will revisit my proposals in the light of the critiques and suggestions received. In the concluding section, I will broaden again the scope towards conceptions of justice, political legitimacy/stability as well as towards possible visions about the future of the EU.

\section{Two perspectives on politics: alternative or complementary?}

My starting point is empirical-theoretical. I have taken stock of the historical developments which led to the consolidation of national (social) citizenship rights and - based on an extensive scholarly literature - have highlighted the key political function they served for state formation. Social rights expanded opportunities and created an area of equality vis-à-vis certain risks and needs; they connected citizens in a web of reciprocal obligations,

This text has been written in the context of the REScEU Project (Reconciling economic and social Europe, www.resceu.eu), funded by the European Research Council (Advanced Grant no. 340534). 
fostered identity and community ties - both having a strong 'bonding' and emotional component. ${ }^{1}$ I see EU citizenship as a novel step in this long term development of right-based citizen empowerment. But I suggest that the integrative and legitimating potential of EU citizenship is not only weaker than its national counterparts, but also ripe with potentially divisive consequences, due to its isopolitical nature. I do acknowledge that workers' mobility can bring and has indeed brought substantial economic advantages. But functional arguments and evaluations play a secondary role in my diagnosis. And while I appreciate Richard Bellamy's friendly effort to extract an unarticulated moral view from my reasoning (a form of cosmopolitanism), my own effort has gone in a different direction: analysing EU citizenship as a political instrument which - regardless of its functional or normative rationale - can produce (or not produce) political cohesion and stability. My questions rest on a realist conception of politics, conceived as the sphere whose foundational task is to 'keep the community together' (of course under democratic constraints in the cases discussed here) and to look at citizenship in this perspective. Bellamy goes some way in my direction when he defends the nation state (and thus boundaries) in instrumental terms, i.e. as the most effective system and territorial container devised so far for safeguarding responsiveness, accountability and equal rights. But my perspective takes an additional step by asking: what are the empirical conditions of possibility for nation-building (or EU- building) and for the political viability over time of the democratic state (or the Union)? And what role can (EU) citizenship play in this context?

Many commentators have either not captured or not appreciated my empirical perspective. Christian Joppke considers my association between national citizenship and political bonding/loyalty as a 'questionable idealisation' and dismisses 'affectual and normative attitudes' towards state authorities as 'delusional at best'. What is the ground of such a severe takedown? If I understood him correctly, Joppke espouses a state theory whereby the protection logic of national citizenship has mainly served to coat the elementary state function of providing security with 'flowery allegiance and loyalty'. As factual judgements, these statements sound quite daring and farfetched to me. The war-welfare nexus has been indeed highlighted by a wealth of comparative historical works. ${ }^{2}$ But even if and when social pro-

Ferrera, M. (2005), The Boundaries of Welfare. European Integration and the New Spatial Politics of Social Protection. Oxford: Oxford University Press.

2 The latest and most up to date work is Obinger, H., K. Petersen and O. Starke (eds.) (2018), Warfare and Welfare: Military Conflict and Welfare State

Development in Western Countries. Oxford: Oxford University Press. 
grammes were originally introduced to 'coat' the warfare goals and strategies of the nation state, their 'protection logic' has subsequently acquired an autonomous dynamic, which in most cases started to generate genuine bonding, loyalty and diffuse support. If this is the historical case, I fail to see why puzzling about the integrative potential of EU citizenship should be "a category mistake". It is precisely by using this category that we can single out the political differences between state-building and EU building and identify the limits and constrains of the latter compared to the former.

Joppke criticises my starting point also from a normative point of view, defining as 'retrograde' my remarks about mobility rights being restricted to EU citizens and not (fully) to third country residents. To begin with, this is today a fact, with factual implications that need to be captured and empirically analysed. Second, as aptly noted by Rainer Bauböck, the dimension of exclusion inheres in any concept denoting membership and inclusion. It is true that, from a normative perspective, the balance between inclusion and exclusion must rest on principled justifications. But, again, my metric is realist-political. Citizenship integrates and legitimises political power to the extent that it 'bounds', that it is a recognisable marker of an insiderhood to which certain selective advantages are associated. I am not formulating a value judgement here; I am not saying that things ought to be this way. What I am saying is that we have empirical evidence that citizenship, when operating within a politically bounded space, has a potential to integrate and legitimise. The 'good' in which I am interested is the political cohesion of the EU. In this sense, and only in this, I make a value choice. But it is only a very weak 'value-related' choice $a$ la Max Weber. I merely believe that it is interesting and important to raise questions about the viability of the EU, given its undeniable conspicuousness as a political entity and its increasing role in shaping people's life chances. Nothing more or less.

The contrast between the empirical and the normative perspective is best exemplified by Frank Vandenbroucke's and Andrea Sangiovanni's wellarticulated contributions. Both outline distinct conceptions of justice for EU solidarity and free movement in particular. And they both embark on this exercise because they deem my reasoning lame (my interpretation), peripheral (Vandenbroucke) or lacking (Sangiovanni) in respect of the more 'foundational' debate about justificatory principles. For them, the basic challenge which I dodge is how to address the question of an ideal (presumably rational and informed) citizen asking, in Sangiovanni's words, 'why should I accept or enhance EU citizenship?'. I concede that my empirical and realist arguments would have little traction indeed were I ever to engage in a philo- 
sophical disputatio of this sort. But would they remain equally unpersuasive if I engaged in a debate with a real world Europhile politician struggling everyday with the problem of consensus? In this situation, it would probably be the philosopher's view that has little traction and might be considered unfit for pragmatic purposes. It is, indeed, a matter of perspective as well as of interlocutors. I locate myself in the real situation of late 2010s Europe; I notice that the fact of free movement causes the fact of Euroscepticism; I surmise that this dynamic may well jeopardise the political stability of the EU as such; I draw on the toolkit of comparative politics and public policy analysis and suggest that a recrafting of EU citizenship might contain this threat. In addition to my fellow political scientists, my interlocutors are essentially the policy-makers. Yes, I confess: the elite. Not because I am dismissive of 'the people' and cynical about the stylised processes of democratic will formation elaborated by political philosophers. But rather because I think that elites are and should not only be spokespersons of their voters, but responsible leaders as well (remember the polemic between Edmund Burke and his Bristol electors?). And, in my perspective, 'keeping the community together' in the face of pluralism and disagreement (and hopefully building constructively on both) is a key task of responsible leaders.

As self-contained conceptions of EU social justice, I do find Sangiovanni's and Vandenbroucke's arguments coherent and largely convincing (with some caveats, starting from those raised by Bauböck). They have an academic, but also a political relevance, to the extent that they can provide valuable symbolic resources to policy-makers puzzling about problemsolving and consensus-building. But - as both authors obviously know - the public acceptance of these arguments cannot be taken for granted. What can be done if there is disagreement? In the philosopher's perspective, one should probably move up one level and interrogate those philosophical doctrines about political justice, which specialise in principles on how to fairly manage disagreements. This regress ad infinitum is however of little use for real world politics and politicians, struggling with conflicts here and now. Without detracting from the importance of principles and normative reasoning, empirical political theory shifts the focus on how institutions and policies relate to system performance and diffuse support. Collective acceptance for the right reasons remains a desirable ideal goal and may even result in greater stability. But, in Weber's wake, empirical political theory conceives of legitimation as a more complex property and process, resting not only on reasons (normative and instrumental) but also on affectual and traditional orientations. It is this mix of motives that allows a real world polity to survive what Ernest Renan called the "daily referendum" on associative life and collective institutions. 
The debate has revealed another misunderstanding that I may have inadvertently originated in my initial contribution and that needs to be cleared. Joppke has raised the worry (which has resonated in other comments as well) that my diagnosis and proposals may bring ammunitions to the enemy, i.e. 'populist demonology'. Let me be crystal clear: in acknowledging the fact of Euroscepticism and the profusely documented increase of chauvinist orientations of European voters, I certainly do not imply that one must be indulgent towards such phenomena, not least because of their manipulative character. On the other hand, a mere judgement of fact cannot be accused of buying into the enemy's views. And while I do agree with Dorte Martinsen that researchers should concentrate on fact finding and perhaps even engage directly 'with the tensions described, be they mainly perceived or real', I must be able to use descriptive categories such as 'stayers' or 'movers' and of analysing observable social and political tensions between them without being accused of covert intelligence with the enemy.

The most appropriate and fruitful conclusion of this discussion on fundamentals is a plea for mutual understanding and collaboration between normativists and empiricists. What $\mathrm{I}$ have in mind is not just a modus vivendi, but the construction of an overlapping consensus whereby: 1) each side makes an effort to acknowledge an equal, if obviously different, theoretical relevance, purchase and autonomy on the other side; 2) both look more closely into each other, especially when normativists make descriptive or causal arguments and empiricists deal with values or undertake political or policy evaluations. To some extent this construction is already under way. ${ }^{3} \mathrm{I}$ find that it is a challenging enterprise, opening novel avenues of research especially for younger scholars.

\section{Citizenship, democracy and European integration}

Magnette's distinction between sympolitical and isopolitical citizenship rights has proven very useful to frame the entire debate. It has also pushed some commentators to focus on the political dimension of citizenship equal participation rights to democratic self-rule. Sandra Seubert is correct in pointing out that I have not adequately addressed this dimension in my historical reconstruction and diagnosis. The European project, Seubert argues, ought to be voluntarily chosen by citizens who consider it as responding to common concerns. If this is not the case, as noted also by Kostakopoulou, then my proposals would just reinforce the problematic

3 See Rossi, E. \& M Sleat (2014), 'Realism in Normative Political Theory', Philosophy Compass 9 (10): 689-701. 
logic that has driven European integration so far: buying consensus by delivering tangible advantages for particular groups. Van Middelaar has defined this logic as the Roman strategy of EU consensus building through panem et circenses - and without even reaping the full benefits of this. ${ }^{4}$

Does my realist perspective inevitably make me a Bismarckian in disguise or, at best, an elitist and paternalist liberal-democrat? Probably yes, if the starting point is a normative preference for participatory democracy based on individual equality and freedom under bottom-up, self-given laws. But that is not the only possible starting point. When I became a political scientist, I started to appreciate 'Schumpeter's other doctrine', i.e. the socalled competitive theory of democracy, which, in my reading, is not an elitist juxtaposition to the participatory view. It rather corrects the latter by bringing back into the democratic scene the important figure of the (wouldbe) elected leader and by drawing attention to the electoral logic as such. In the real world, free elections inescapably activate a quid pro quo dynamic whereby whats (policy programmes inspired by different values and ideologies) are exchanged for whos (votes in support of competing political leaders promising whats). On this view, political citizenship confers an equal (if minimal) power resource - the individual vote - which can be spent during electoral exchanges. Democratic rights of political participation logically presuppose civil rights and are in their turn instrumental for the acquisition and defence of social rights. Once the whole package is in place, the famous Marshallian tryptic generates mutual synergies; citizenship not only acquires a self-sustaining equilibrium but becomes a unique instrument for taming and controlling vertical power through the multiplication of the horizontal powers and endowments of citizens, in their various social roles and life situations. The keystone of this system is sympolitical closure. Who gets what, how and when is the result of domestic democratic politics, which produces collectively binding sovereign decisions. Domestic markets - for goods, services, capital and labour - can of course be (made) open. But key national decisions result from citizens' endogenous preferences on how to manage the consequences of openness and define/redefine its boundaries. My conclusion is not dissimilar from Seubert's (democratic empowerment is the core) but on my view the core is derived from empirical, not normative theory.

Gradually, and to some extent creepingly, the EU has lifted the sympolitical keystone. Isopolitical integration has caused increasing cross-system externalities which can no longer be democratically managed at either the national or the supranational level. The EU is today a quite peculiar political

4 Van Middelaar, L. (2013), The Passage to Europe, How a Continent became Europe. New Haven: Yale University Press. 
system which defies all our analytical categories. We say it is "far from federal". But in certain policy areas regulatory standardisation linked to free movement has gone way beyond the limits that historical federations (such as the USA or Switzerland) have not dared to trespass. Swiss cantons still enjoy wider margins of residency-based 'discrimination' than EU member states. In the US it is true that 'states cannot select their citizens', especially when it comes to welfare, as Martin Seeleib-Kaiser reminds us. But they can, for example, charge higher fees to out-of-state students applying to state universities and delay residence requests by students for the mere purpose of paying lower fees. The Court of Justice of the European Union (CJEU) has become a hyper-federal watchdog of EU law and its supremacy over national law - with serious social consequences, as correctly highlighted by Susanne Schmidt. Another indicator of hyper-federalism is the extent to which some policy decisions are delegated to non-majoritarian institutions with very wide regulatory autonomy (e.g. as regards state aids, competition, or banking supervision). It is true that this institutional architecture has resulted from 'demoicratic' procedures and decisions in the past (the CJEU was born from the Rome Treaty, the ECB from the Maastricht Treaty, and so on). But the fact is that today such institutions find themselves far removed from the basic form of democratic control: the vote of individual citizens. In some other core areas of state power (e.g. fiscal policy: taxing and spending) we are under the illusion that the EU only rests on intergovernmental coordination. But we use intergovernmentalism as an indicator of inter-nationalism, in Bellamy's sense: a two level game in which national citizens mandate their governments to negotiate inter-national agreements under the implicit assumption that subsequent decisions under these agreements remain responsive and accountable to national citizens. This is no longer the case. Under the reformed Growth and Stability Pact, the Commission's decisions on macroeconomic imbalances or budget deficits (decisions which may have huge consequences for ordinary citizens) can be rejected only through a reverse qualified majority rule, which has been (correctly in my view) equated with 'minority rule'. ${ }^{5}$ I am afraid that the EU has long ago ceased to conform to that 'republican inter-nationalist' blueprint praised by Bellamy. And I think this also obtains for the intuitively appealing demoicratic formula of 'governing together, but not as one' ${ }^{6}$ If my diagnosis is correct, in key policy areas the EU has already become a

\footnotetext{
5 Daniele, L., P. Simone \& P. Cisotta (eds.) (2017), Democracy in the EMU in the Aftermath of the Crisis. Berlin: Springer.

6 According to the famous formula as understood by Nicolaidis. See Nicolaidis K. (2013), 'European Demoicracy and Its Crisis', Journal of Common Market Studies 51 (2): 351-369.
} 
powerful 'one', in which some demoi (not to speak of some citizens) are more equal than others.

What are the consequences of this opaque regime (that we find very hard to define in terms of democratic theory) for the Marshallian triptych described above? The least that we can say is that the new regime has entirely destructured the coherence of the triptych and heavily undermined its effectiveness and even viability. Strangely enough, this situation has been endogenously generated. Democratic sympolitical decisions have originally authorised isopolitical standardisation of economic and civil rights. Such decisions have also deliberately transferred some sympolitical sovereignty to the supranational level. The latter has gradually undermined the content and quality of domestic social rights. The hands of national citizens have been tied: in certain domains their votes have become ineffective or no longer requested. It is unclear which majorities prevail, in some cases the rules even allow minorities to prevail.

A full account of how we got here is way beyond the scope of this rejoinder. $^{7}$ Empirical political theory suggests that to some extent we have been victims of unintended consequences and perverse effects of institutional logics. We should also be careful not to neglect the enormous advantages that integration has produced: not only more aggregate welfare, but also robust safeguards for peace and security. As noted by Bauböck, the EU was born to anchor the post-war system of fragile and shattered democracies. And still today we badly need it to secure the conditions of possibility for democracy in Europe. I would add a second consolation. Political supranationalisation has partly served - especially in certain member states - as a beneficial constraint for irresponsible domestic choices in taxing and spending and as an incentive to engage in responsible strategies of functional and distributive rationalisations. There were important cross-national variations in the coherence and balance of the Marshallian tryptic and some did need significant corrections, especially in terms of financial duties (see below).

The bottom line of my reasoning is, however, that the EU citizenship regime(s) are currently skewed and unstable. Let me then turn to the question of what can be done, focusing on one particular instrument: EU citizenship in its social and duty components.

7 For an updated debate, see Chalmers, D., M. Jachtenfuchs \& C. Joerges (eds.) (2016), The End of the Eurocrats' Dream. Cambridge: Cambridge University Press. 


\section{Caring Europe, my proposals and the 'holding environment'}

Agreeing with my diagnosis about a growing tension between stayers and movers, Van Parijs identifies three fundamental strategies of response. The first ('all movers'; we could also call it 'more of the same') consists in 'converting as many stay-at-homes as possible into movers'. Since a total conversion would be obviously impossible, let us say that this strategy should rest on persuading the stayers to internalise the functional and normative rationales of mobility as a collective benefit. But empirical evidence tells us that an increasing number of stayers do not (no longer) buy into that view. The 'all movers' strategy is not a solution, but an aggravation of the political problem. The second strategy is 'retreat', i.e. curtailing those isopolitical rights that cause the problem. I did not discuss retreat in my introduction, but yes, I believe that there is room for some steps in this direction. ${ }^{8}$ I fully agree, for example, with Schmidt that limits should be posed to the judicialisation of citizenship. I also think that the mobility regime can be partially reconfigured in a restrictive direction through secondary legislation alone - no Treaty changes needed. The third strategy is 'Caring Europe', which was first submitted to EU leaders in exactly this wording by a group of scholars (myself included) during the UK presidency of the EU in 2005, under Tony Blair. ${ }^{9}$ The political rationale of Caring Europe is not Bismarckian. And while this strategy alone cannot remedy the loss of individual democratic control, it can indeed kill three birds with one stone: 1) it can backstop the centrifugal, Eurosceptic dynamics as well as the destabilisation of the Marshallian triptych; 2) it can safeguard the functional and social justice advantages ingrained in free movement; 3 ) it can contribute to the overall durability of the EU polity by thus preserving the otherwise vulnerable pre-conditions of peace and democracy in Europe (Bauböck's argument).

The Caring Europe strategy has precisely informed my concrete proposals, so let me now revisit them in the light of the debate. Both Seeleib-Kaiser and Ilaria Madama underline that there is already more ground than meets the eye for implementing some of my proposals and that the Commission is well aware of the need to integrate stayers in the mobility and social agenda of the EU. This should at least partly overcome the scepticism of Martinsen who is worried about the lack of time and political support for my proposals to mate-

8 Ferrera, M. (2017), 'The Contentious Politics of Hospitality. Intra-EU mobility and social rights', European Law Journal 22 (6): 791-805.

9 Giddens, A. (ed.) (2006), The Hampton Court Agenda: a Social Model for Europe. London: Policy Network. 
rialise swiftly. To a large extent, my proposals merely go in the direction of a political rationalisation of the status quo: reaping all the consensus building potential of those instruments that are already available. One might ask: if it is so easy, why has it not been done already? The answer lies in the level at which such decisions are taken and the interests/views of decision-makers at that level. Making sure that the EU role can be captured at the street level and "in the last mile" or introducing a social card is not today European Council stuff. These nitty gritty provisions are decided by the lower echelons of EU and national bureaucracies, primarily interested in administrative and practical details. Last mile implementation is under the radar of local politicians ready to capture the credit of any panes or circenses accruing to their voters. The integrative and legitimising potential of my proposals should be brought to the attention of top leaders, those who are ultimately responsible for the EU's stability and durability. The launch of a social card for accessing all the already existing co-funded programmes of the EU that provide advantages to all citizens, whether stayers or movers (as well as the enhancement and greater visibility of the external protection advantages of the EU passport) should be promoted by top leaders and could be done rather easily.

The introduction of a voucher scheme (and I like Theresa Kuhn's idea of using in some way the label 'mobility bonus') and of a universal skills guarantee (maybe also a 'children guarantee') require sympolitical agreement. But the skills guarantee is already on the agenda: it could well be deliberately crafted so as to maximise its visibility to the stayers. Some commentators (Sangiovanni, Vandenbroucke, Hermann, Hemerijck) have rightly noted that mobility may not only generate some losses for the stayers of the countries of destination, but also of the countries of origin (e.g. through brain drain). Here the solution could be an active involvement of the EU in sponsoring 'return mobility' programmes. The Central and Eastern member states have already launched national initiatives in this direction to bring back home the 'drained brains' and to help the relocation of their nationals residing in the UK. EU complements to such initiatives would be a very good idea. A sympolitical consensus on a dedicated EU insurance scheme for mobile workers is more difficult to piece together, I acknowledge this. This proposal has been around for many decades, without attracting the attentions it deserved. What is required here is a shift from functional to political attention, in a context of increasing contention about mobility. A similar (and more demanding) shift is needed also for the possible introduction of an EU fund against cyclical unemployment. Here the obstacles concern not only political consensus building, but also epistemic convergence, given the currently prevailing obsessions about 'moral hazard' on the side of ordoliberal elites and experts. More than a century of experience with mass social insur- 
ance against unemployment at the domestic level (initially opposed precisely on moral hazard grounds) should indicate however that there are ways of containing the risk and that the risk itself is not so high after all.

Some commentators have themselves made additional proposals in the logic of a Caring Europe. There is no space to enter into the details and I do share the logic (if not all the details) of such additional suggestions. I would like to briefly comment, however, on the more ambitious strategy outlined by Vandenbroucke and Anton Hemerijck about moving towards a European Social Union of some sort. ${ }^{10}$ Under this approach, the core of social sovereignty should remain at the national level, where redistributive issues can still largely (but not entirely) be dealt with via national sympolitical decisions. In Vandenbroucke's contribution, one task of the Union should be to make sure that member states do guarantee (via binding constraints or surveillance?) sufficient social provisions and legal minimum wages for whoever legally resides within their territory. In Hemerijick's contribution, the Union should essentially provide a 'holding environment' for an effective functioning of national social protection systems. If I understand him correctly, Hemerijck espouses a 'softer' overall approach, in the logic of the Lisbon and EU2020 agendas, which now underpin the newly created European Pillar of Social Rights. And he is not sure whether it is essential for the EU to claim political credit for its institutional scaffolding. In addition, he feels half way between the inter-national position of Richard Bellamy and my alleged supra-national position. But as I argued above, supranationalism is already with us, and rather 'hype' in some policy areas. Taking it apart - at least to a certain degree - may be functionally and normatively desirable. But is it institutionally feasible, short of a financial/monetary catastrophe? Brexit is teaching us how difficult it is for member states to disentangle themselves from the EU in ways which are decently reasonable in normative and instrumental terms. In this sense, I fully agree with Bauböck that the EU has become a community of - 'prosaic and not at all romantic' - destiny. It is the famous historical institutionalist argument about the temporal quasiirreversibility of complex institutions (you cannot put the toothpaste back into the tube once you have squeezed it out). My doubts about Hemerijck's softer and semi-internationalist notion of a socially friendly 'holding environment' (HE) are fourfold. First, would it imply a partial dismantling of the

10 I have outlined and justified my own position on the European Social Union in Ferrera, M. (2017), 'The European Social Union: a missing but necessary "political good", in Vandenbroucke, F, C. Barnard \& G. Febaere (eds.), A European Social Union after the Crisis, 3-46. Cambridge: Cambridge University Press. 
supranationalist excesses that we now have (as proposed, among others, by Fritz Scharpf)? ${ }^{11}$ Would this HE essentially be a top-down construction promoted by enlightened leaders, technocrats and experts? Is it realistic to expect that HE would reinforce 'loyalty to the EU as a common possession of a union of welfare states' in the eyes of voters already mobilised by antiEU parties? And finally, how can we manage the dangerous and destructive politicisation that free movement has already triggered off? My modest proposals for the short term are motivated by these latter developments. But also for the long term, I think that we should definitely have a plausible and deliberate legitimation strategy for the EU (even as a holding environment) which will never be effective without at least a modicum of "Roman policies" (i.e. resource transfers).

\section{What about duties?}

The question of duties has remained somewhat in the shadows of the debate. In my initial contribution I had myself been cautious and modest on this front. The link between duties, and especially tax paying duties, and legitimacy is complex and full of strains. Many of the existing Eurosceptic parties were born as anti-tax parties. If our aim is to enhance the integrative potential of citizenship, we should tread very lightly on this terrain, adopting, as I suggested, a nudging rather than a binding strategy.

Since Joppke has launched an attack on the very idea that citizenship ought to imply duties, I feel a duty to respond. I understand that in normative and legal theory there is an articulated debate on this issue. I do not enter into this debate but will try to summarise my realist approach, in the hope of making my normativist colleagues aware of the essentials of the empirical theory on rights and duties. The production of political goods (policies and generalised compliance) requires 'extractions' from the members of the territorial community, the most obvious exemplars of which have historically been conscription and taxes. Are these extractions part of the citizenship package? Definitely yes, in my perspective. As the etymology of the term clearly suggests, being a citizen means being a member of a civitas, a legally constituted collectivity. Since extractions are a precondition for the survival of the latter, a citizen cannot avoid the duties of membership which inhere in her very status as such. Fulfilling one's duties (which also and predominantly means, in ordinary life, to respect the rights of fellow citizens and the prerogatives of the authorities) is key for the success of the "daily referendum" on the political community. Without gener-

11 Scharpf, F. (2016), 'De-Constitutionalization and Majority Rule. A Democratic Vision for Europe', MPIfG Discussion Paper 16/14. 
alised compliance, political stability is at risk. The formal titularity of a right is a precondition for its actual exercise. But the exercise is effective only to the extent that there is both horizontal (on the side of other citizens) and vertical (on the side of the authorities) compliance, i.e. the observance of those duties which are correlative of rights. The correspondence of rights and duties is especially important in the case of social entitlements, which entail financial resources. As mentioned above, in various countries the increasing gap between the actual fruition of social entitlements and tax/contributory duties or compliance (e.g. through evasion or the black economy) has led to acute sustainability problems for the welfare state. To a significant extent, such problems have also resulted from irresponsible political choices, i.e. the conferral of entitlements not underpinned by adequate duties of financial participation.

Why do citizens fulfil their duties? In my perspective, this is immaterial. Some may do that 'for the right reasons', some for habit, custom, romantic affection. As I said above, in real world polities, legitimacy rests on a mix of motives. Is the correspondence between rights and duties the product of a coherent historical trajectory and deliberate strategy? Not at all. Citizenship is a symbol that came gradually to encompass pre-existing national patchworks of rights and duties, got intertwined with the parallel symbol of "nationality' and turned into a basic status, that of 'having rights to have rights' within a bounded space. The symbol over-emphasised the rights side of membership, but it always implied a second side, i.e. the duty to accept duties.

It is certainly true that the substance of the citizenship package has been gradually extended to all legal residents (with the key exception of sympolitical participation rights). But as long as state boundaries remain a fact, the status of citizenship entails a vertical empowerment vis-à-vis territorial authorities which aliens or denizens do not have and through which citizen can define and redefine the rules of access and the content of the denizenship status itself.

Even if ordinary people do not visualise this clearly, the EU is a bounded territorial collectivity. Although derivative of national citizenship, EU citizenship does confer novel isopolitical civil and social rights and their correlative duties as well as novel sympolitical rights through the European Parliament. As I have argued above, the large majority of citizens are 'stayers'. They have to comply with one class of isopolitical duties (accepting mobile workers as equals in the labour market and welfare state) without de facto exercising the corresponding isopolitical rights. Their capacity to change this situation through sympolitical rule making has been curtailed domestically and is still weak supranationally. I do not share Hemerijck's theory according to which 
EU citizenship was adopted to seal the internal market. Historical reconstructions show that the new provisions of the Maastricht Treaty (also) reflected the social and political strategy of EU building of leaders such as Jacques Delors. Whether by design or by failure, the fact is that rather than complementing national citizenship regimes, EU citizenship has ended up destabilising them. My proposals aim at a political rebalancing. In this perspective, I believe that a smart gradual strategy of soft dutification of EU citizenship, initially based on nudging, might have positive and virtuous political effects. Kuhn worries that such nudging would only activate those who are already in favour of the EU. So be it. My survey data show that the share of EU voters that do favour cross national or pan-European forms of solidarity exceeds the share of cosmopolitans. ${ }^{12}$ Eurosceptics are extremely vocal, but their numbers oscillate between 15 per cent and 30 per cent, depending on the member state. Pro-EU voters are still a large majority, but this majority is silent and disoriented. Adding stuff to EU citizenship and some nudging for its dutitification could provide, precisely, a focus to coalesce around the Caring Europe agenda.

\section{Conflicts and visions on the future of Europe}

Time to conclude. My realist perspective is only loosely related to values. It rests on a Weberian value relation and then emphasises the centrality of instrumental political goods, which have to do with safeguarding 'what is necessary to maintain democracy' (Bauböck) so that it can produce the final goods that free and equal citizens decide to pursue. Do I have a personal normative conception about integration? Yes, I do, and it belongs to the same liberal egalitarian cluster of the explicit or implicit conceptions espoused by most of our commentators. ${ }^{13}$ But I have chosen here to keep my reasoning at a meta-level. And at this levels normative conceptions are political 'objects' which contribute to providing a collective sense of purpose that can motivate citizens to belong together. A vibrant intellectual debate on ultimate purposes is very important for institution building and polity maintenance. EU building is a novel experiment in political unification of different national communities, undertaken within a (now) unfavourable historical constellation characterised by an overall de-freezing of the economic, social and cultural patterns of modernity. We perceive a pervasive and foundational change, a general "melting of all that was solid", but we seem unable

12 Ferrera, M. \& A. Pellegata (undated), Reconciling economic and social Europe. Report on the REScEU Survey, available at http://www.resceu.eu/ events-news/news/can-economic-and-social-europe-be-reconciled-citizens'view-on-integration-and-solidarity.html.

13 Ferrera, M. (2014), 'Solidarity in Europe after the Crisis', Constellations 21 (2): $222-238$. 
to define this change in positive terms rather than merely as an ambiguous contrast to the past (post-modernism, post-nationalism, post-democracy, post-materialism, post-capitalism, etc.). Without 'pros-eutopian' (from the Greek pros, before us) visions of the future, we should not be surprised about the return of nostalgic and backward looking 'retrotopias' (to use Zygmunt Bauman's metaphor). ${ }^{14}$

I mentioned above Schumpeter's distinction between the 'classical' and the 'other' doctrine of democracy and I have argued that they should be seen as two sides of the same coin, the latter as a 'vertical' correction to the former. I now conclude by recommending an additional correction. Democratic participation and competition must be infused with values. Equal and free participation and proceduralised power struggles among elites only define the perimeters of a playing ground where substantive interests, ideas and values contend with each other. The emphasis on values (on the polytheistic fight among them) as a quintessential element of politics in the sense of Berufspolitik is a major legacy of Weber's political theory, including his often misinterpreted theory of democracy. 'Man would not have attained the possible unless time and again he had reached out for the impossible' is the famous Weberian motto concluding his speech on "Politics as a Profession". As social scientists (normative and empirical) we can contribute to producing visions of the impossible. But the outreachers ought to be political actors: responsible, pros-eutopian and, I would add, also Euro-phile politicians.

Open Access This chapter is licensed under the terms of the Creative Commons Attribution 4.0 International License (http://creativecommons.org/licenses/by/4.0/), which permits use, sharing, adaptation, distribution and reproduction in any medium or format, as long as you give appropriate credit to the original author(s) and the source, provide a link to the Creative Commons license and indicate if changes were made.

The images or other third party material in this chapter are included in the chapter's Creative Commons license, unless indicated otherwise in a credit line to the material. If material is not included in the chapter's Creative Commons license and your intended use is not permitted by statutory regulation or exceeds the permitted use, you will need to obtain permission directly from the copyright holder.

14 Bauman, Z. (2017), Retrotopia. London: Polity. 